\title{
KEHAMILAN TETAP SEHAT DI MASA PANDEMI
}

\author{
Riona Sanjaya1), Hellen Febriyanti'1), Yetty Dwi Fara1), Septika Yani Veronica1), Siti Maesaroh'), \\ Alfiyanti Muharramah ${ }^{2)}$, Tri Adi Nugroho3)
}

\author{
1)Program Studi Kebidanan Program Sarjana Terapan, Fakultas Kesehatan, Universitas Aisyah Pringsewu, \\ Lampung, Indonesia \\ 2)Program Studi S1 Gizi, Fakultas Kesehatan, Universitas Aisyah Pringsewu, Lampung, Indonesia \\ 3)Program Studi S1 Keperawatan, Fakultas Kesehatan, Universitas Aisyah Pringsewu, Lampung, Indonesia
}

Corresponding author : Riona Sanjaya, Siti Maesaroh.

E-mail : riona2212@gmail.com

\section{Diterima 19 Februari 2021, Direvisi 28 Juli 2021, Disetujui 28 Juli 2021}

\begin{abstract}
ABSTRAK
Kehamilan merupakan proses yang normal, alamiah yang diawali dengan pertumbuhan dan perkembangan janin intrauteri, dimulai sejak konsepsi sampai bersalin dan lamanya kehamilan normal adalah 280 hari (40 minggu atau 9 bulan 7 hari) di hitung dari hari pertama haid terakhir. Pada masa Kehamilan ibu hamil agar dapat mempersiapkan diri pada kesehatan ibu hamil dengan menjaga nutrisi selama proses kehamilannya. Ibu hamil wajib memeriksakan kehamilannya agara ibu hamil dapat mengetahui dan mencegah sedini mungkin kelainan yang dapat terjadi, meningkatkan kondisi badan ibu dalam menghadapi kehamilan serta mendapatkan penyuluhan yang diperlukan selama kehamilan. Melalui kegiatan ini diharapkan masyarakat khususnya ibu hamil mampu menjaga kesehatannya selama kehamilan di masa pandemi. Kegiatan-kegiatan ini mencakup teori dan praktek yang meliputi : (1) Pendidikan Kesehatan yang dilakukan secara online; (2) Praktik Senam Ibu Hamil yang dilakukan Melalui Vidio; dengan melibatkan mahasiswa Universitas Aisyah Pringsewu pada saat pelaksanaan. Melalui kegiatan ini, diharapkan masyarakat khususnya ibu hamil dapat menyadari pentingnya kesehatan bagi ibu hamil walaupun dimasa pandemi ini.
\end{abstract}

Kata kunci: kehamilan; nutrisi; senam hamil

\begin{abstract}
Pregnancy is a normal, natural process that begins with the growth and development of the intrauterine fetus. It starts from conception to delivery and the normal length of pregnancy is 280 days (40 weeks or 9 months 7 days) on the first day of the last menstruation. During pregnancy, pregnant women can prepare themselves for the health of pregnant women by maintaining nutrition during the pregnancy process. Pregnant women are required to have their pregnancy checked so that pregnant women can find out and prevent possible abnormalities that can occur, improve the condition of the mother's body in facing pregnancy and get the necessary counseling during pregnancy. Through this activity, it is expected that the community, especially pregnant women, will be able to maintain their health during pregnancy during a pandemic. These activities include theory and practice as follows: (1) Health Education which will be conducted online; (2) Exercise for Pregnant Women through Video; by involving the students of Aisyah University of Pringsewu during the implementation. In the other hand, it can realize the importance of health for pregnant women even during this pandemic.
\end{abstract}

Keywords: pregnancy; nutrition; pregnancy exercise

\section{PENDAHULUAN}

Masa Prakonsepsi, kehamilan dan menyusui merupakan fase dalam siklus kehidupan yang memerlukan perhatian khusus terutama dari segi pencukupan kebutuhan energi dan zat gizinya. Status gizi wanita yang optimal dalam masa persiapan kehamilan merupakan hal yang krusial dan mempengaruhi outcame dari kehamilan. Kecukupan energi makro saat kehamilan juga memengaruhi pertumbungan janin dalam kandungan dan tumbuh kembang bayi. Berbagai hambatan yang muncul saat hamil tidak jarang memengaruhi asupan makan ibu, dikhawatirkan jika asupan nutrisi ibu kurang maka akan berpengaruh dengan janin ibu.(Anggraeny \& Ariestiningsih, 2017)

lbu hamil harus selalu menjaga nutrisi dan kesehatannya terutama dimasa pandemi covid sepeti saat ini. Ibu hamil termasuk kelompok yang rentan terkena covid. Berdasarkan hal tersebut maka pencegahan yang dapat dilakukan pada ibu hamil yaitu dengan menjaga asupan makanan untuk 
pemenuhan zat gizi selama kehamilan, selain itu konsumsi makanan yang bervariasi dan seimbang dari masa prakonsepsi sangat penting untuk memastikan kesehatan ibu. Pastikan ibu hamil mempunyai diet makanan yang bervariasi dan seimbang selama hamil yang sesuai dengan makanan selama hamil. Ibu hamil akan mengalami keuntungan pada masa kehamilan yaitu tubuh ibu akan memiliki kemampuan yang lebih tinggi dan efisien dalam menyerap nutrisi makanan.(Suririnah, 2010)

Menjaga pola makan yang sehat selama kehamilan akan mendukung pertumbuhan janin yang normal. Banyak ibu hamil yang tidak menyadari pentingnya menjaga status gizi yang optimal selama kehamilan. Tidak mengetahui pemilihan makanan yang tepat, kurang mengawasi perubahan berat badan, serta seringnya mengkonsumsi suplemen vitamin dan mineral untuk mencukupi status gizi ibu hamil. Ibu perlu menjaga kebugaran tubuh ibu dan mendukung pertumbuhan janin yang normal.(Panel on Dietetic Products, 2013) Sayur dan buah buahan merupakan jenis bahan pangan yanga mengandung serat. Sayur dan buah sangat penting dalam menu makan seimbang karena merupakan sumber vitamin dan mineral.(Sagita, Sanjaya, Fara, \& Maesaroh, 2020)

Asupan zat gizi pada ibu hamil akan terus mengalami peningkatan berdasarkan trimester kehamilan, yang dapat dipenuhi dengan sedikit peningkatan asupan energi, dalam keseimbangan yang seimbang antara makronutrien dalam rekomendasi pedoman kecukupan zat gizi. Kebutuhan kalori pada masa kehamilan menunjukkan kebutuhan tambahan $69 \mathrm{kkal} /$ hari untuk trimester pertama, $266 \mathrm{kkal} /$ hari untuk trimester kedua dan $496 \mathrm{kkal} \mathrm{/} \mathrm{hari} \mathrm{pada} \mathrm{trimester} \mathrm{ketiga}$ kehamilan (dengan total tambahan 76.530 kkal).(Emilia, 2010)

Pola makanan yang sehat merupakan bagian penting dalam pola kehidupan pada setiap siklus kehidupan. Termaksud ketika sedang menjalani kehamilan. Pengaturan makan yang baik bukan berarti ibu harus menjalani diet yang tidak sesuai. lbu hanya perlu mengkonsumsi makanan yang cukup dari sumber yang bervariasi setiap hari sehingga kebutuhan ibu dan janin dalam rahim dapat terpenuhi. Ibu hamil juga harus menghindari beberapa jenis makanan dan mengutamakan untuk mengkonsumsi makanan yang aman.(Cetin, Berti, Mandò, \& Parisi, 2011)

Selama kehamilan, kebutuhan zat besi semakin meningkat hingga bulan ketiga, seiring dengan penumpukan di jaringan janin.(Allen, 2000) Asupan yang tidak memadai selama kehamilan terkait dengan peningkatan kebutuhan zat besi membuat ibu hamil berisiko lebih besar mengalami kekurangan zat besi, yang dapat mempengaruhi pertumbuhan dan perkembangan janin dan meningkatkan risiko kelahiran prematur, berat badan lahir rendah dan perdarahan pasca melahirkan.(Khambalia et al., 2016)

Selain asupan nutrisi, ibu hamil juga membutuhkan latihan fisik ringan guna menjaga Kesehatan ibu dan janinnya. Seperti olahraga jalan pagi, senam hamil, yoga, pilates, hypnotherapy dan sebagainya.(Fauziah, Sanjaya, \& Novianasari, 2020)

Pemerintah selama pandemi memberikan kebijakan pembatasan kunjungan antenatal guna menekan penyebaran virus, kecuali pada kasus - kasus tertentu atau dengan perjanjian temu sebelumnya. Sehingga ibu hamil dituntut untuk bisa memahami isi buku Kesehatan Ibu Dan Anak (KIA) yang dimiliki, atau dapat berkonsultasi dalam jaringan (daring) dengan petugas Kesehatan. Sehingga ibu masih tetap mendapatkan informasi yang menunjang kesehatannya. Kegiatan ini bertujuan sebagai upaya peningkatan pengetahuan ibu hamil agar tetap dapat menjaga kesehatannya dimasa pandemi, dengan Latihan fisik ringan dan pemenuhan kebutuhan nutrisi yang adekuat.

\section{METODE}

Pengabdian masyarakat (pengabmas) ini dilakukan pada hari Selasa 22 Desember 2020. Strategi yang digunakan mengatasi permasalahan diatas adalah pendekatan berbasis komunitas dimana startegi pemecahan langsung ke sasaran yaitu lbu hamil trimester II dan III di Desa Pungguk Lama Kabupaten Lampung Utara, sejumlah 21 orang. Kegiatan penyuluhan dan praktik senam hamil menggunakan media power point, audio visual (video) serta demontrasi senam hamil. Metode yang digunakan meliputi ceramah, tanya jawab, diskusi dan penayangan video senam hamil serta demontrasi senam hamil. Tahap kegiatan ini dimulai dengan pre test, persentase materi, demontrasi senam hamil dan ditutup dengan post test.

\section{HASIL DAN PEMBAHASAN}

Kegiatan pengabdian kepada masyarakat (Pengabmas) dilaksanakan sesuai dengan tahapan yang terdiri dari

\section{Pre Test}

Peserta kegiatan di Desa Pungguk Lama Dusun Pungguk Jaya Kecamatan Abung Timur Kabupaten Lampung Utara. Pengabdian ini dilaksanakan pada tanggal 22 Desember 
2020 yang di awali dengan memperkenalkan diri dan maksud serta tujuan dari acara pengabdian. Kemudian memberikan pertanyaan pre test terkait materi yang akan disampaikan kepada seluruh peserta, guna menggali informasi serta sejauh mana pengetahuan peserta terkait gizi ibu hamil serta menjaga kehamilan tetap sehat dimasa pandemi sebelum mengikuti kegiatan. Alokasi waktu yang diberikan adalah 20 menit. Hasil pre test di peroleh rata-rata 53,3 tertuang dalam matrik sebagai berikut:

四 Wawasan

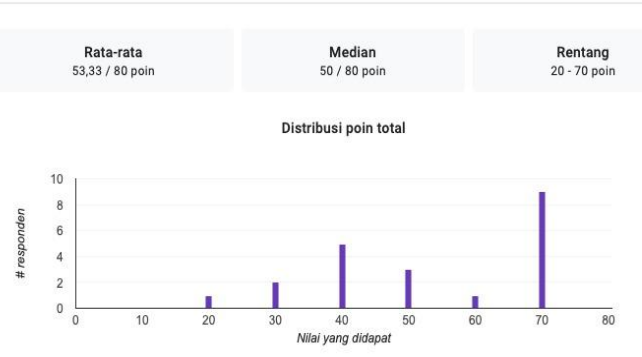

Gambar 1. Matrik Hasil Pre test

\section{Persentasi Materi}

Persentasi

dilakukan untuk menyampaikan informasi secara umum terkait gizi ibu hamil dan menjaga kehamilan tetap sehat dimasa pendemi.

Prinsip pencegahan COVID-19 pada ibu hamil, bersalin dan nifas di masyarakat meliputi universal precaution dengan selalu cuci tangan memakai sabun selama 20 detik atau hand sanitizer, pemakaian alat pelindung diri, menjaga kondisi tubuh dengan rajin olah raga dan istirahat yang cukup, memakan makanan dengan gizi seimbang, dan mempraktikkan etika batuk dan bersin.(Kemenkes RI, 2020) Sehingga selama pandemi ibu hamil dapat menjaga kesehatannya.

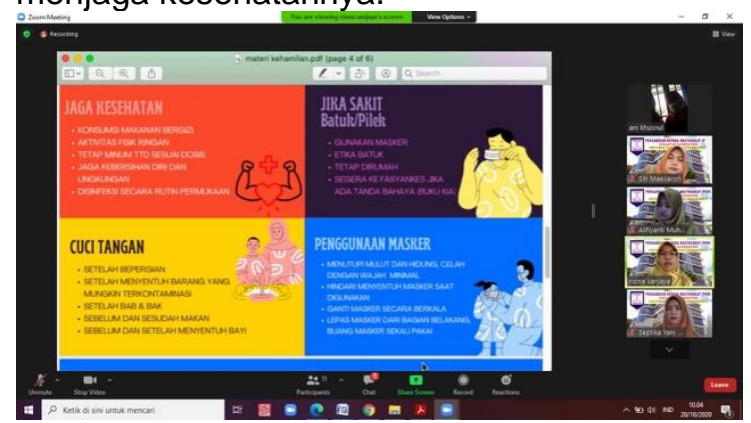

Gambar 2. Persentasi materi penyuluhan

Penjelasan yang disampaikan (Gambar 2) meliputi cara menjaga kehamilan sehat dimasa pandemi yang bisa ibu terapkan dirumah, seperti pada ibu hamil pemeriksaan kehamilan selama pandemi dilakukan dengan perjanjian sebelumnya, pelajari buku KIA termasuk mengenali tanda bahaya pada kehamilan, menjaga Kesehatan selama hamil dengan makan - makanan bergizi seimbang, menjaga kebersihan diri dan tetap beraktivitas fisik seperti melakukan senam hamil, serta tetap meminum table $\mathrm{Fe}$ sesuai dosis yang diberikan, namun ibu hamil yang terkonfirmasi positif covid tidak diberikan tablet tambah darah.(Kemenkes RI, 2020)

Materi disampaikan melalui zoom meeting dengan metode ceramah, materi yang disampaikan tentang gizi ibu hamil dan kehamilan tetap sehat dimasa pendemi. Alokasi waktu materi selama 30 menit.

\section{Demontrasi Senam Hamil}

Praktik senam hamil diberikan dengan pemutaran video senam hamil (Gambar 3) yang telah disiapkan oleh tim. Peserta di dampingi mahasiswa program studi kebidanan dalam melakukan praktik senam hamil.

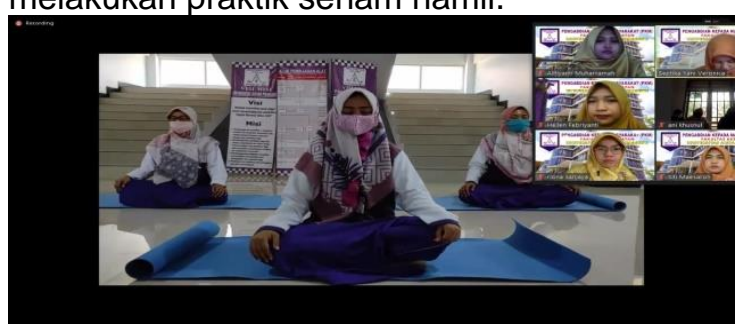

Gambar. 3 Foto demonstrasi senam hamil

Saat praktik senam hamil peserta dipastikan sudah mengenakan pakaian yang nyaman dan menyerap keringat, memastikan selalu terhidrasi, usia kehamilan lebih dari 24 minggu dan tidak memiliki kontraindikasi melakukan senam hamil. Peserta dapat berhenti melakukan senam hamil kapanpun ibu merasa lelah/tidak nyaman.

\section{Post Test}

Kegiatan ini dilaksanakan dengan tujuan untuk mengetahui kemampuan peserta setelah mengikuti kegiatan. Peserta diberikan soal terkait materi yang disampaikan. Alokasi waktu yang diberikan adalah 20 menit.

Hasil yang diperoleh terdapat peningkatan pengetahuan peserta pengabmas dari rata-rata 53,3 meningkat menjadi 70,5. Hasil post test tertuang dalam matrik seperti yang ditunjukkan pada gambar 4 . 


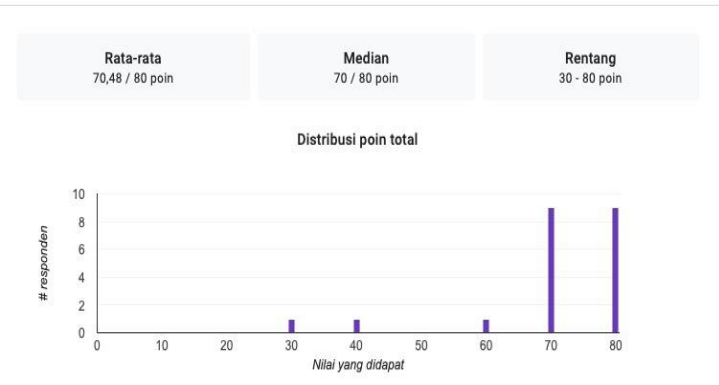

Gambar 4. Matrik Hasil Post test

\section{SIMPULAN DAN SARAN}

Terdapat peningkatan pengetahuan ibu hamil trimester II dan III di Desa Pungguk Lama Dusun Pungguk Jaya Kecamatan Abung Timur Lampung Utara tentang menjaga kesehatan dimasa pandemi, dari rata - rata nilai pre test 53,3 meningkat menjadi 70,5 pada post test.

\section{DAFTAR RUJUKAN}

Allen, L. H. (2000). Anemia and iron deficiency: effects on pregnancy outcome. The American Journal of Clinical Nutrition, 71(5), 1280S-1284S.

Anggraeny, O., \& Ariestiningsih, A. D. (2017). Gizi Prakonsepsi, Kehamilan, dan Menyusui. Universitas Brawijaya Press.

Cetin, I., Berti, C., Mandò, C., \& Parisi, F. (2011). Placental iron transport and maternal absorption. Annals of Nutrition and Metabolism, 59(1), 55-58.

Emilia, O. (2010). Tetap bugar dan energi selama hamil. Jakarta: PT AgroMedia Pustaka.

Fauziah, N. A., Sanjaya, R., \& Novianasari, R. (2020). PENGARUH PRENATAL YOGA TERHADAP PENGURANGAN NYERI PUNGGUNG PADA IBU HAMIL TRIMESTER III. Jurnal Maternitas Aisyah (JAMAN AISYAH), 1(2), 134-140.

Kemenkes RI. (2020). PEDOMAN BAGI IBU HAMIL, BERSALIN, NIFAS DAN BAYI BARU LAHIR Di Era Pandemi COVID-19. Jakarta.

Khambalia, A. Z., Collins, C. E., Roberts, C. L., Morris, J. M., Powell, K. L., Tasevski, V., \& Nassar, N. (2016). Iron deficiency in early pregnancy using serum ferritin and soluble transferrin receptor concentrations are associated with pregnancy and birth outcomes. European Journal of Clinical Nutrition, 70(3), 358-363.

Panel on Dietetic Products, N. and A. (NDA). (2013). Scientific opinion on dietary reference values for energy. EFSA J, 11(3005-3016).

Sagita, Y. D., Sanjaya, R., Fara, Y. D., \&
Maesaroh, S. (2020). PENINGKATAN PENGETAHUAN KONSUMSI BUAH DAN SAYUR PADA ANAK SEKOLAH DASAR. Jurnal Pengabdian Kepada Masyarakat Ungu (ABDI KE UNGU), 2(1), 1-5.

Suririnah. (2010). Buku pintar kehamilan dan persalinan. Jakarta: PT Gramedia Pustaka Utama. 